\title{
ANALISIS PENERAPAN KEBIJAKAN MONETER SUKU BUNGA JANGKA PENDEK PADA VARIABEL-VARIABEL ENDOGEN MAKROEKONOMI INDONESIA
}

\author{
Sari Damayanti \\ School of Business Management, Bina Nusantara University \\ Jln. K.H. Syahdan No.9, Palmerah, Jakarta Barat 11480 \\ smdamayanti@gmail.com
}

\begin{abstract}
This study analyzed the impact of the implementation of monetary policy through short-term interest rates setting on the variation that occurs in the endogenous variables of Indonesian macro economy in the period of 2000-2009 by implementing the Structural Vector Autoregressive approach (SVAR) which is the development of Vector Autoregressive (VAR) modelling with Eviews program. By careful examination of the results, this study indicates that the value of interest rate changes is significantly associated with shocks that are associated with monetary policy. The monetary sector is heavily influenced by real GDP shock, liquidity, and inflation shock. However, the monetary sector is only slightly affected by the decomposition of the variance of the exchange rate, which is very sensitive to the inflation shock. The study also indicates that the endogenous variables in the value of changes in interest rates and real exchange rate of rupiah will be close to convergence in the long term. The endogenous variables are more susceptible to changes in variables derived from domestic, such as the level of demand for domestic currency liquidity, compared to variables derived from international capital exposure. Thus, the value of the variable interest rate changes can be used to reduce the potential risks derived from domestic money demand shock.
\end{abstract}

Keywords: Structural Vector Autoregressive (SVAR), liquidity shock, real GDP shock, inflation shock, variance decomposition

\begin{abstract}
ABSTRAK
Penelitian ini bertujuan untuk menganalisis dampak dari penerapan kebijakan moneter melalui penetapan suku bunga jangka pendek pada variabel-variabel endogen makroekonomi Indonesia pada periode 2000-2009 dengan mengimplementasikan pendekatan Structural Vector Autoregressive (SVAR). Hasil penelitian menunjukkan bahwa nilai perubahan suku bunga secara signifikan berhubungan dengan shock yang timbul dari kebijakan moneter. Sektor moneter sangat dipengaruhi oleh real GDP shock, liquidity shock, dan inflation shock, tetapi tidak terlalu dipengaruhi dekomposisi varians dari nilai tukar yang sangat sensitif dari inflation shock. Hasil penelitian juga menunjukkan variabel-variabel endogen dalam nilai perubahan suku bunga dan nilai tukar riil rupiah akan konvergen pada jangka panjang. Variabel-variabel endogen tersebut lebih sensitif terhadap perubahan variabel likuiditas permintaan mata uang domestik dibandingkan dengan variabel yang berasal dari eksposur penanaman modal asing. Oleh karena itu, kebijakan moneter pada variabel perubahan suku bunga dapat digunakan untuk membantu mengurangi potensi risiko yang berasal dari shock terhadap permintaan mata uang domestik.
\end{abstract}

Kata kunci: Structural Vector Autoregressive (SVAR), shock likuiditas, shock riil GDP, shock inflasi, dekomposisi varians 


\section{PENDAHULUAN}

Shock atau guncangan ekonomi dapat disebabkan oleh perubahan permintaan agregat (demand shock) maupun perubahan penawaran agregat (supply shock). Indikasi shock terhadap perekonomian secara umum dapat dipahami melalui mekanisme permintaan dan penawaran, yang diterjemahkan melalui dua saluran transmisi, yaitu goncangan yang negatif pada sisi penawaran (negative supply side shock) dan goncangan yang negatif pada sisi permintaaan (negative demand-side shock). Pendapatan dan belanja riil di negara-negara importir akan berkurang. Dengan demikian, transmisi kenaikan harga minyak melalui kedua saluran tersebut akan menyebabkan berkurangnya permintaan agregat (aggregate demand) dan penawaran agregat (aggregate supply), yang selanjutnya akan membawa implikasi turunnya output atau melemahnya pertumbuhan ekonomi.

Secara spesifik, efek perubahan dari kebijakan perekonomian yang mengatur kinerja variabel makroekonomi dapat dijelaskan melalui beberapa mekanisme transmisi moneter sebagai berikut. Pertama, efek guncangan sisi penawaran (supply-side shock effect) yang berfokus pada dampak langsung perubahan biaya marginal produksi dan pengurangan keuntungan perusahaan yang disebabkan oleh guncangan harga minyak terhadap output perekonomian. Kedua, efek transfer pendapatan (wealth transfer effect) yang menekankan pada perubahan angka konsumsi marginal dari petrodollar dan surplus perdagangan. Ketiga, efek inflasi (inflation effect) yang menganalisis hubungan antara inflasi domestik dan harga minyak. Keempat, efek penyesuaian sektor yang mengestimasi penyesuaian biaya sektoral dari industri, yang secara utama dipergunakan untuk menjelaskan dampak guncangan harga minyak; dan kelima, efek yang tidak diantisipasi (unexpected effect) yang menganalisis kondisi ketidakpastian dalam perekonomian.

Lebih lanjut, mekanisme transmisi kebijakan moneter adalah proses yang melaluinya keputusan kebijakan moneter ditransmisikan melalui perubahan GDP riil dan inflasi (Taylor, 1995). Proses transmisi tersebut dipengaruhi oleh tiga faktor: (1) perubahan perilaku bank sentral, perbankan, dan para pelaku ekonomi dalam berbagai aktivitas ekonomi dan keuangan, (2) tenggang waktu (lag) sejak kebijakan moneter ditempuh sampai sasaran inflasi tercapai, dan (3) perubahan pada saluransaluran transmisi moneter sesuai dengan perkembangan ekonomi dan keuangan di negara yang bersangkutan.

Pada dasarnya transmisi kebijakan moneter merupakan interaksi antara otoritas moneter atau bank sentral dengan perbankan dan lembaga keuangan lainnya serta para pelaku ekonomi di sektor riil. Interaksi ini terjadi dalam dua tahap. Tahap pertama adalah transaksi keuangan antara bank sentral dengan perbankan dan lembaga keuangan. Tahap berikutnya adalah berkaitan dengan fungsi intermediasi, yaitu transaksi antara perbankan/lembaga keuangan lainnya dengan para pelaku ekonomi dalam berbagai aktivitas ekonomi riil. Sejalan dengan perkembangan yang cukup pesat dalam bidang ekonomi dan keuangan saluran transmisi kebijakan moneter ini terbagi dalam beberapa saluran (channel). Warjiyo (2004) membagi transmisi kebijakan moneter menjadi lima saluran, yaitu saluran langsung (direct channel), saluran suku bunga (interest rate channel), saluran harga aset (asset price channel), saluran kredit (credit channel), dan ekspektasi (expectation channel).

Penelitian ini berfokus pada saluran suku bunga (interest rate channel). Saluran ini lebih menekankan pada pentingnya harga dalam pasar keuangan yang memengaruhi inflasi dan sektor riil. Saluran ini juga menekankan pada pengaruh harga terhadap perkembangan berbagai suku bunga di sektor keuangan. Sebuah catatan yang cukup penting bagi transmisi ini adalah peranan suku bunga riil lebih berpengaruh terhadap konsumsi dan investasi dibandingkan suku bunga nominal. Dari mekanisme transmisi ini dapat diketahui bahwa kebijakan moneter masih tetap efektif meskipun tingkat suku bunga nominal ditetapkan 0 (nol) oleh otoritas moneter. 
Perkembangan suku bunga di sektor keuangan ini sangat berkaitan dengan permintaan konsumsi dan investasi. Pengaruh suku bunga terhadap konsumsi berkaitan dengan peranan suku bunga sebagai komponen pendapatan masyarakat (income effect) dan komponen bunga kredit sebagai sumber pembiayaan konsumsi (substitution effect). Sementara itu, pengaruh suku bunga terhadap investasi terjadi karena suku bunga merupakan unsur biaya modal (cost of capital). Pengaruh perubahan suku bunga terhadap konsumsi dan investasi akan berdampak pada permintaan agregat yang selanjutnya akan berdampak pula terhadap inflasi dan sektor riil.

\section{METODE}

Penelitian ini menggunakan metode SVAR untuk menganalisis dampak guncangan ekonomi terhadap perekonomian Indonesia. Analisis penelitian ini adalah dengan permodelan Structural Vector Autoregressive (SVAR) yang merupakan pengembangan dari permodelan Vector Autoregressive (VAR) dengan menggunakan program Eviews. Data yang digunakan pada penelitian ini adalah data moneter Indonesia. Data moneter tersebut kemudian dianalisis dengan pendekatan SVAR yang mengikuti langkah-langkah analisis Mirdala (2009). Mirdala (2009) menganalisis pengaruh dari kebijakan moneter bank sentral di negara-negara Visegard pada beberapa variabel makroekonomi dalam periode 1999-2008 dengan mengimplementasikan pendekatan SVAR. Hasil dari penelitian Mirdala (2009) menunjukkan bahwa tingkat sensivitas yang tinggi pada indikator makroekonomi di negara-negara kandidat EMU (Economic and Monetary Union) terhadap shocks dari kebijakan moneter nasional mengindikasikan tingginya tingkat exposure negara-negara tersebut terhadap kebijakan moneter ECB (European Central Bank) setelah proses pengadopsian Euro pada masa datang.

Penelitian ini didasarkan pada pengukuran lima variabel yang berpengaruh terhadap perekonomian Indonesia untuk menganalisis pengaruh guncangan luar negeri terhadap perekonomian domestik dalam konteks perekonomian terbuka. Dua variabel di antaranya merupakan non-policy variable yaitu output (GDP) dan tingkat harga (CPI) yang menggambarkan kondisi ekonomi Indonesia. Sedangkan tiga variabel lainnya merupakan policy variable yaitu suku bunga domestik (BI Rate), jumlah uang beredar (M1), dan nilai tukar riil efektif (REER).

Data yang digunakan dalam penelitian ini adalah data time series bulanan selama kurun waktu 2000-2009. Pemilihan periode ini didasarkan pada pertimbangan bahwa dalam kurun waktu tersebut kondisi perekonomian dalam keadaan relatif stabil.

Penelitian ini menggunakan metode Stuctural Vector Autoregressive (SVAR) untuk mengestimasi impulse response dari suatu shock. SVAR merupakan bentuk Vector Autoregressive (VAR) yang terestriksi. Pada SVAR, restriksi ditempatkan berdasarkan hubungan teoritis yang kuat pada skema (peta hubungan) bentuk urutan (ordering) variabel-variabel yang digunakan dalam sistem VAR. Model SVAR digunakan untuk memperoleh ortogonalisasi non-recursive dari error term dalam kerangka analisis impulse response. Untuk memperoleh ortogonalisasi non-recursive error term, maka harus dibentuk sejumlah restriksi yang mengidentifikasi komponen struktural dalam error term.

Latar berlakang penggunaan model SVAR didasarkan pada beberapa keunggulan SVAR. SVAR hanya memerlukan sedikit restriksi untuk memisahkan pergerakan variabel endogen ke dalam bagian-bagian dengan mengacu pada underlying shock, SVAR menyertai beberapa alat analisis yang berguna untuk menjawab pertanyaan yang berkaitan dengan efek suatu shock dan efek periode waktu yaitu impulse response function dan variance decomposition, dan SVAR mudah digunakan untuk melakukan estimasi. 
Permodelan SVAR pada paper ini didasarkan pada restriksi jangka panjang terhadap model VAR yang tidak direstriksi. Model VAR yang tidak direstriksi direpresentasikan oleh representasi moving average sebagai berikut.

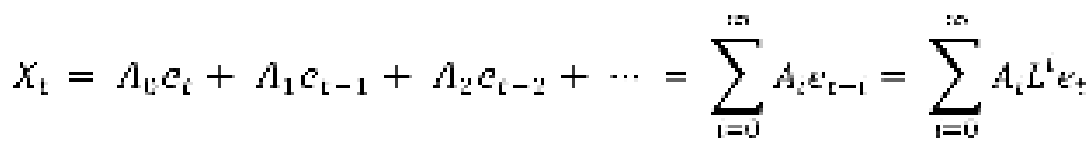

$$
\begin{aligned}
& \text { atau } \\
& X_{1}=A(L) o_{\mathrm{L}}
\end{aligned}
$$

$\mathrm{X}$ adalah vector dari variabel endogen makroekonomi, $\mathrm{A}(\mathrm{L})$ adalah polynomial variancecovariance matriks dari lag-length $l, \mathrm{~L}$ adalah lag operator dan e adalah vektor dari shock dalam reduced form pada elemen $\mathrm{X}$.

Analisis SVAR dalam penelitian ini dilakukan dengan memplot data series. Plot data series dari vektor $\mathrm{X}$ yang terdiri dari lima variabel-variabel endogen yang dimodifikasi dari model Takatoshi dan Liyotaka (2006) yaitu: real output $(y=R G D P)$, core inflation $(p=C P I)$, money supply $(m=M 1)$, short-term market interest $(I=I R)$, dan exchange rate $(e=R E R)$.

Untuk dapat mengidentifikasi structural shocks dengan baik, harus ditentukan 15 restriksi. Lima restriksi diperoleh dengan menormalkan matriks orisinal. Sepuluh restriksi long-run mengidentifikasikan restriksi sebagai berikut: (1) demand shock tidak mempunyai pengaruh yang permanen terhadap (a) inflasi , (b) money supply, (c) dan real exchange rate; (2) inflation shock tidak mempunyai pengaruh yang permanen terhadap (d) real output, (e) money supply, dan (f) real exchange rate; (3) liquidity shock tidak mempunyai pengaruh yang permanen terhadap (g) real output dan (h) real exchange rate; (4) monetary shock tidak mempunyai pengaruh yang permanen terhadap (i) money supply dan (j) real exchange rate.

Setelah menetapkan identifikasi restriksi jangka panjang, maka, $X_{i}=A(L) \varkappa_{i}$ dapat ditulis dalam bentuk, $X_{i}=B(\mathcal{L}) \mathrm{it}_{\mathrm{i}}$.

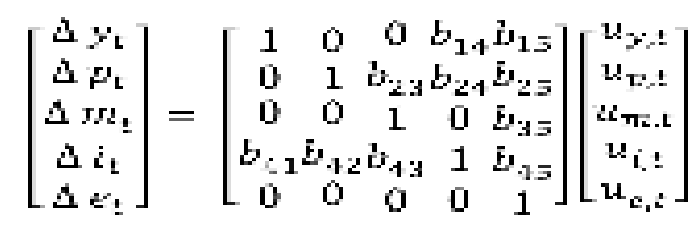

$B(L)$ adalah sebuah matriks polynomial variance-covariance yang berisikan respons dari variabel-variabel endogenous terhadap structural disturbances yang mendasarinya; $L$ adalah lag operator; dan $u$ adalah vektor dari identically normally distributed, serially uncorrelated dan mutually orthogonal (normalized) white noise disturbances (identified structural shocks). Vektor dari struktural shocks ut terdiri dari identified demand shock $\left(\mathrm{u}_{\mathrm{y}, \mathrm{t}}\right)$, inflation shock $\left(\mathrm{u}_{\mathrm{p}, \mathrm{t}}\right)$, liquidity shock $\left(\mathrm{u}_{\mathrm{m}, \mathrm{t}}\right)$, monetary policy shock $\left(\mathrm{u}_{\mathrm{i}, \mathrm{t}}\right)$, exchange rates shock $\left(\mathrm{u}_{\mathrm{e}, \mathrm{t}}\right)$.

Estimasi model SVAR membantu untuk menilai variance decomposition dari variabelvariabel endogenous dari model; menentukan kontribusi dari shock kebijakan moneter terhadap real $G D P$, core inflation, money supply, dan short-term interest rates; dan RER (real exchange rate) conditional variance untuk menentukan respons mereka terhadap shock kebijakan struktural moneter dengan satu standar deviasi (inovasi). 


\section{HASIL DAN PEMBAHASAN}

Interpretasi data pada lima variabel endogen adalah sebagai berikut. Data real GDP memiliki kecenderungan yang menurun di setiap waktunya. Data Consumer Price Index (CPI) memiliki kecenderungan yang meningkat pada setiap waktunya. Data Money supply (M1) atau data dari jumlah uang yang beredar berfluktuasi dengan tren yang meningkat. Data Interest Rate (IR) atau data dari suku bunga kebijakan domestik berfluktuasi tinggi dengan kecenderungan yang menurun. Sedangkan data Real Exchange Rate (RER) berfluktuasi tinggi dengan kecenderungan yang meningkat.

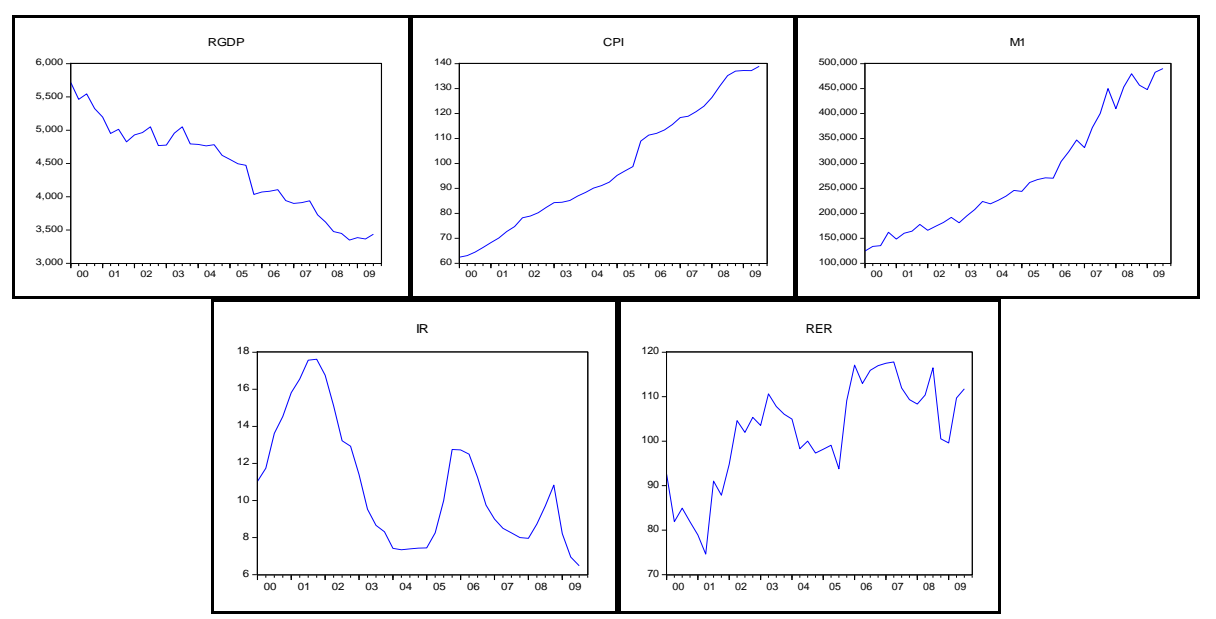

Gambar 1 Plot Data Series RGDP, CPI, M1, IR, dan RER

Pengujian stasioneritas dilakukan untuk menghindari spurious regression atau regresi palsu. Dalam menentukan stasioneritas variabel, maka dilakukan uji unit root sesuai dengan bentuk tren deterministik yang terkandung dalam setiap variabel dengan menggunakan uji Augmented Dickey Fuller (ADF) dan uji Phillips-Perron (PP).

Interpretasi uji ADF pada lima variabel endogen pada Tabel 1 adalah sebagai berikut. Variabel RGDP tidak stasioner dalam level maupun dalam bentuk first difference (diferensiasi pertama). Variabel CPI tidak stasioner dalam level, tetapi stasioner dalam bentuk first difference. Variabel M1 tidak stasioner dalam level maupun dalam bentuk first difference. Variabel IR tidak stasioner dalam level, tetapi stasioner dalam bentuk first difference. Variabel RER tidak stasioner dalam level, tetapi stasioner dalam bentuk first difference.

Tabel 1 Hasil Uji Stasioneritas ADF-Test

\begin{tabular}{lllcrcrc}
\hline Variabel & \multicolumn{1}{c}{ Uji URT } & $\begin{array}{c}\text { Tren Deter- } \\
\text { ministik }\end{array}$ & $\begin{array}{c}\text { Prob. } \\
\text { MacKinnon (1996) } \\
\text { one-sided p-values. }\end{array}$ & ADF Test & $\begin{array}{c}\text { CV } \\
(\mathbf{1 0 \%})\end{array}$ & Stasioner \\
\hline RGDP & Level & Konstanta, trend & 0.1604 & -2.950613 & -3.207094 & Tidak \\
(trend) & First Difference & Konstanta, trend & 0.4815 & -2.186543 & -3.207094 & Tidak \\
CPI & Level & Konstanta, trend & 0.5668 & -2.029866 & -3.198312 & Tidak \\
(intercept) & First Difference & Konstanta, trend & 0.0012 & -5.043925 & -3.200320 & Ya \\
M1 & Level & Konstanta, trend & 0.4801 & -2.189249 & -3.207094 & Tidak \\
(trend) & First Difference & Konstanta, trend & 0.7523 & -1.647397 & -3.207094 & Tidak \\
IR & Level & Konstanta, trend & 0.3006 & -1.964304 & -2.610263 & Tidak \\
(intercept) & First Difference & Konstanta, trend & 0.0377 & -3.070699 & -2.610263 & Ya \\
RER & Level & Konstanta, trend & 0.4117 & -1.723547 & -2.609066 & Tidak \\
(intercept) & First Difference & Konstanta, trend & 0.0000 & -7.247646 & -2.610263 & Ya \\
\hline
\end{tabular}


Hasil dari uji unit root dengan metode Augmented Dickey-Fuller, dengan derajat keyakinan 99\%, diketahui bahwa tidak ada variabel yang stasioner dalam level. Sedangkan variabel yang stasioner dalam bentuk first difference adalah variabel CPI, variabel IR, dan variabel RER. Selain itu diketahui pula bahwa variabel RGDP dan variabel M1 tidak stasioner pada semua variabel dalam uji ADF.

Interpretasi uji PP pada lima variabel endogen (Tabel 2) adalah sebagai berikut. Variabel RGDP tidak stasioner dalam Level, tetapi stasioner dalam bentuk first difference. Variabel CPI tidak stasioner dalam Level, tetapi stasioner dalam bentuk first difference. Variabel M1 tidak stasioner dalam Level, tetapi stasioner dalam bentuk first difference. Variabel IR tidak stasioner dalam Level, tetapi stasioner dalam bentuk first difference. Variabel RER tidak stasioner dalam Level, tetapi stasioner dalam bentuk first difference. Dengan metode Phillips-Perron tersebut, dengan derajat keyakinan 99\%, diketahui bahwa walaupun tidak ada variable yang stasioner dalam level, semua variabel yaitu RGDP, CPI, M1, IR dan RER stasioner dalam bentuk first difference.

Tabel 2 Hasil Uji Stasioneritas Phillips-Perron

\begin{tabular}{|c|c|c|c|c|c|c|}
\hline Variabel & Uji URT & $\begin{array}{l}\text { Tren Deter- } \\
\text { ministik }\end{array}$ & $\begin{array}{c}\text { Prob. } \\
\text { MacKinnon (1996) } \\
\text { one-sided p-values. }\end{array}$ & PP Test & CV $(10 \%)$ & Stasioner \\
\hline RGDP & Level & Konstanta, trend & 0.1850 & -2.863950 & -3.198312 & Tidak \\
\hline (trend) & First Difference & Konstanta, trend & 0.0000 & -9.707020 & -3.200320 & $\mathrm{Ya}$ \\
\hline CPI & Level & Konstanta, trend & 0.5002 & -2.154476 & -3.198312 & Tidak \\
\hline (intercept) & First Difference & Konstanta, trend & 0.0015 & -4.954526 & -3.200320 & Ya \\
\hline M1 & Level & Konstanta, trend & 0.6876 & -1.794701 & -3.198312 & Tidak \\
\hline (trend) & First Difference & Konstanta, trend & 0.0000 & -10.64299 & -3.200320 & $\mathrm{Ya}$ \\
\hline IR & Level & Konstanta, trend & 0.6003 & -1.341207 & -2.609066 & Tidak \\
\hline (intercept) & First Difference & Konstanta, trend & 0.0367 & -3.082019 & -2.610263 & $\mathrm{Ya}$ \\
\hline RER & Level & Konstanta, trend & 0.4720 & -1.601539 & -2.609066 & Tidak \\
\hline (intercept) & First Difference & Konstanta, trend & 0.0000 & -7.247646 & -2.610263 & Ya \\
\hline
\end{tabular}

Hasil uji ADF menunjukkan bahwa kedua variabel-RGDP dan M1-tidak stasioner baik dalam level maupun dalam bentuk first difference. Sedangkan hasil uji PP menunjukkan bahwa walaupun variabel RGDP dan variabel M1 tidak stasioner pada level, kedua variabel tersebut stasioner dalam bentuk first difference. Hal ini terjadi karena dalam periode tersebut terdapat shocks pada ekonomi yang menyebabkan adanya structural break. Metode Phillips-Perron sangat tepat untuk data yang memiliki structural break sehingga hasil uji stasioneritas dalam kondisi structural break ini berpedoman pada uji PP.

Pengujian kointegrasi menggunakan model Johansen. Model Johansen dapat menguji kointegrasi pada persamaan sistem (system equation), tetapi tidak menuntut adanya sebaran data yang normal. Berdasarkan hasil pengujian tes kointegrasi Johansen terlihat bahwa terdapat indikasi kointegrasi di antara variabel endogenus. Oleh karena itu hal tersebut berimplikasi bahwa variabelvariabel tersebut akan membentuk hubungan pada periode long-run equilibrium. Setelah mencapai kestasioneran, pada tahapan selanjutnya dapat dilakukan kalkulasi dekomposisi varians dan impulseresponse function (IRF) dari variabel endogen. 


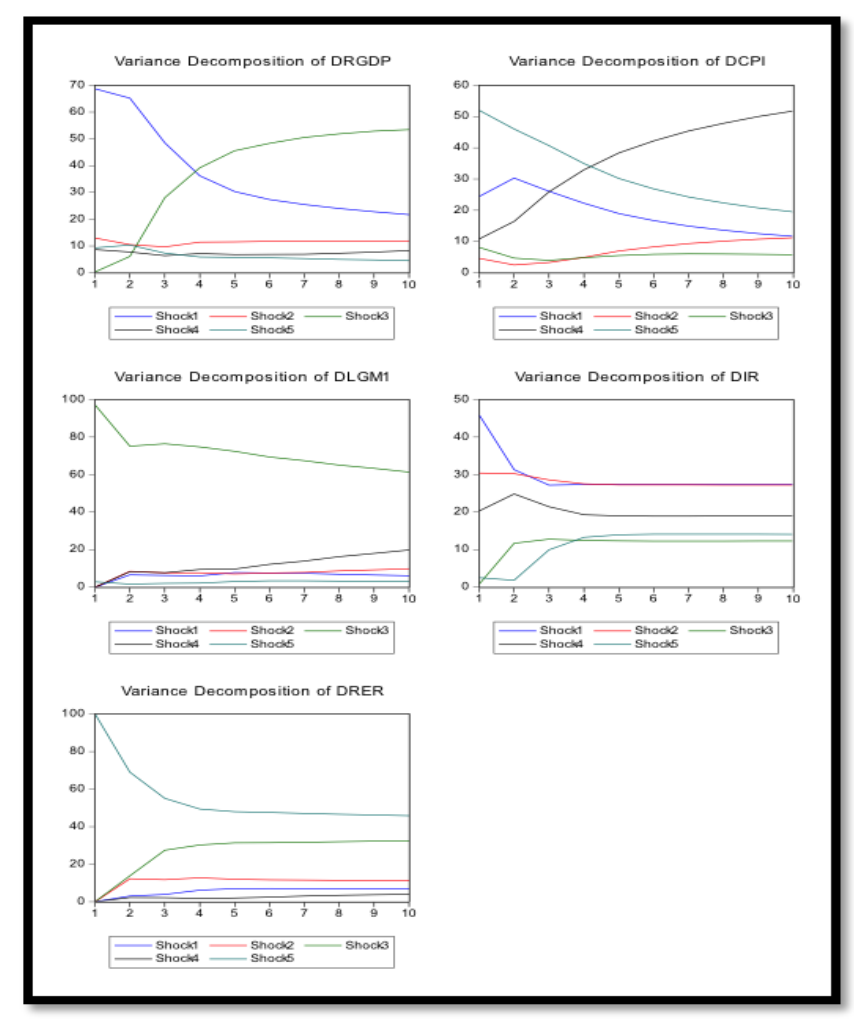

Gambar 2 Dekomposisi Varians dari 5 Variabel dalam Model

Hasil uji dekomposisi varians pada Gambar 2 menunjukkan kontribusi dari setiap structural shock terhadap component conditional variance yang endogen. Sedangkan dari hasil uji IRF dapat diketahui respons dari komponen endogen pada satu standar deviasi structural shock. Output yang disajikan dalam bentuk plot untuk mengetahui polanya. Interpretasi hasil difokuskan untuk menganalisis efek shock kebijakan moneter pada variasi yang terjadi dalam variabel-variabel endogen. Hal ini dimaksudkan agar dapat melihat dampak dari penerapan kebijakan moneter melalui penetapan interest rate jangka pendek.

Dekomposisi varians (variance decomposition) dalam model VAR bertujuan untuk memisahkan pengaruh masing-masing variabel inovasi secara individual terhadap respons yang diterima suatu variabel termasuk inovasi dari variabel itu sendiri. Dekomposisi varians dari output riil merefleksikan dominannya kenaikan yang berasal dari pengaruh liquidity shock pada GDP riil selama tahun pengamatan. Liquidity shock biasanya berkaitan dengan foreign capital inflow. Sedangkan dekomposisi varians dari inflasi mengindikasikan kuatnya pengaruh bank sentral untuk mengontrol tekanan yang menyebabkan inflasi. Dalam hal ini terlihat bahwa variabel yang kuat memengaruhi tingkat inflasi adalah adanya demand shock. Dekomposisi varians dari likuiditas menunjukkan pengaruh yang cukup kuat dari demand shock dibandingkan misalnya dengan monetary policy shock, dan nampaknya pengaruh yang paling lemah berasal dari dari shock nilai tukar. Sektor moneter yang direpresentasikan di sini dengan interest rate, sangat dipengaruhi oleh shock GDP riil. Liquidity shock dan inflation shock juga cukup memberikan kontribusi. Dekomposisi varians exchange rate sangat sensitif dari shock inflasi, sebaliknya sangat kecil pengaruh dari shock kebijakan moneter.

Impulse response function yang menjelaskan respons dari variabel terhadap structural shock dapat dilihat pada Gambar 3. Estimasi terhadap fungsi impulse response dilakukan untuk memeriksa respons kejutan (shock) variabel inovasi terhadap variabel-variabel lainnya. Estimasi menggunakan asumsi masing-masing variabel inovasi tidak berkorelasi satu sama lain, sehingga penelurusan 
pengaruh suatu kejutan dapat bersifat langsung. Gambar impulse response akan menunjukkan respons suatu variabel akibat kejutan variabel lainnya sampai dengan beberapa periode setelah terjadi shock. Jika gambar impulse response menunjukkan pergerakan yang makin mendekati titik keseimbangan (convergence) atau kembali ke keseimbangan sebelumnya, respons suatu variabel akibat suatu kejutan makin lama akan menghilang sehingga kejutan tersebut tidak meninggalkan pengaruh permanen terhadap variabel tersebut.

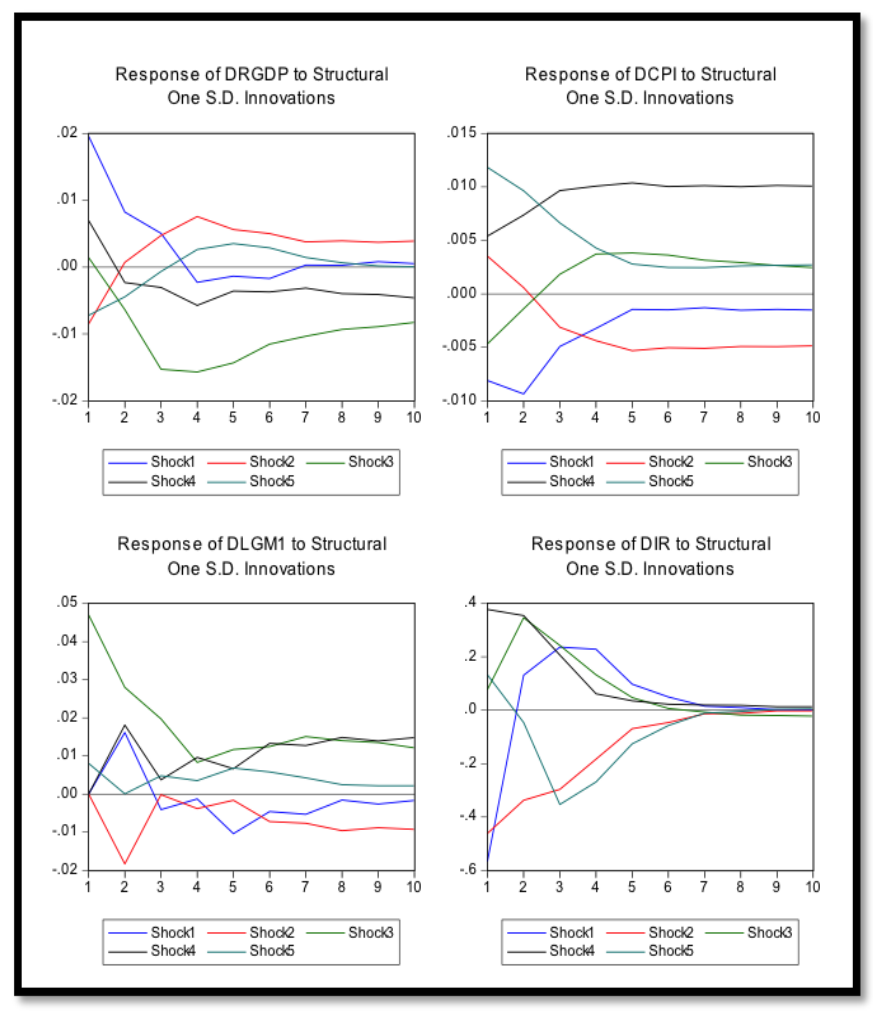

Gambar 3 Hasil Impulse Response dari Variabel-variabel Endogen pada Model

Gambar 3 menjelaskan fungsi impulse response pada sepuluh kuartal setelah shock selama periode pengamatan. Secara umum gambaran khusus yang dapat dilihat dari impulse response function seluruh variabel adalah kekuatan shock dari likuiditas yang tinggi. Pada gambar pertama dapat dilihat pengamatan respons yang diterima oleh pertumbuhan GDP akibat shock pertumbuhan inflasi selama sepuluh kuartal bersifat convergence. Dengan demikian kejutan pertumbuhan inflasi akan direspons oleh pertumbuhan GDP namun tidak bersifat permanen. Pertumbuhan GDP akan mengalami selfcorrecting setelah pengaruh inflasi sudah berbalik tanda (arah). Sementara dampak respons yang diterima pertumbuhan GDP akibat variabel lainnya tidak convergence. Gambar berikutnya menunjukkan hasil pengamatan yang serupa yang respons dari inflasi akibat dampak dari shock seluruh variabel tidak satupun bersifat convergence. Hal ini berarti bahwa respons pertumbuhan inflasi sebagai akibat shock setiap variabel makin lama tidak akan menghilang, sehingga shock dari seluruh variabel pengamatan terhadap pertumbuhan inflasi berpengaruh secara permanen. Gambar ini menunjukkan adanya respons negatif (kontraksi) dari shock pertumbuhan GDP. Berikutnya adalah respons dari pertumbuhan likuiditas sebagai dampak dari shock variabel pengamatan. Seperti respons yang dialami oleh pertumbuhan inflasi, respons pertumbuhan likuiditas akibat shock dari setiap variabel pengamatan tidak ada yang convergence. 
Oleh karena itu dapat dikatakan shock dari seluruh variabel pengamatan terhadap pertumbuhan likuiditas terus berpengaruh secara permanen dalam jangka panjang. Hasil yang berbeda ditunjukkan oleh gambar berikutnya yaitu respons kebijakan moneter sebagai dampak dari setiap variabel selama sepuluh kuartal bersifat convergence. Hal ini menunjukkan bahwa shock setiap variabel akan direspons oleh kebijakan moneter walaupun tidak bersifat permanen. Selain itu terdapat pula respons negatif dari kebijakan moneter akibat adanya shock pertumbuhan inflasi dan pertumbuhan nilai tukar. Sedangkan respons pertumbuhan nilai tukar sebagai dampak variabelvariabel pengamatan dapat dilihat ada shock dari tiga variabel yaitu pertumbuhan GDP, perubahan kebijakan moneter, dan pertumbuhan nilai tukar seperti terlihat pada Gambar 4 berikut.

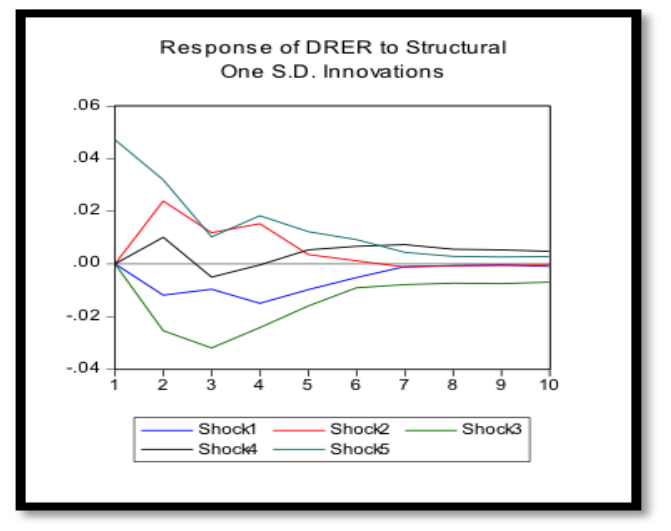

Gambar 4 Impulse Response dari Pertumbuhan Nilai Tukar dari Pengamatan Shock dari Variabel Endogen Lainnya

Pada shock dari tiga variabel tersebut akan berpengaruh secara permanen selama 10 periode pengamatan karena pergerakannya bersifat convergence. Sedangkan shock dari dua variabel lainnya yaitu pertumbuhan inflasi dan pertumbuhan likuiditas tidak bersifat permanen dalam 10 periode karena respons yang diterima oleh pertumbuhan nilai tukar tidak bersifat permanen.

\section{SIMPULAN}

Estimasi dalam penelitian ini didasarkan pada model SVAR dengan tujuan menganalisis sumber pergerakan atau perubahan nilai riil GDP, nilai inflasi, nilai perubahan liquiditas (M1), suku bunga pada periode jangka pendek, dan nilai riil pertukaran Rupiah. Hasil estimasi variance decomposition menunjukkan kontribusi dari setiap structural shock terhadap component conditional variance yang endogen. Sedangkan dari hasil estimasi Impulse Response Function (IRF) dapat diketahui respons dari komponen endogen pada satu standar deviasi structural shock. Meskipun begitu, hasil dari estimasi variance decomposition tidak dapat menjelaskan "efisiensi" mekanisme transmisi perubahan suku bunga.

Interpretasi hasil difokuskan untuk menganalisis efek shock kebijakan moneter pada variasi yang terjadi dalam variabel-variabel endogen. Hal ini dimaksudkan agar dapat melihat dampak dari penerapan kebijakan moneter melalui penetapan suku bunga jangka pendek. Melalui hasil estimasi maupun grafis, maka dapat disimpulkan bahwa dekomposisi varians dari output riil merefleksikan dominannya kenaikan yang berasal dari pengaruh liquidity shock pada GDP riil selama tahun pengamatan. Liquidity shock biasanya berkaitan dengan foreign capital inflow. Sedangkan dekomposisi varians dari inflasi mengindikasikan kuatnya pengaruh bank sentral untuk mengontrol 
tekanan yang menyebabkan inflasi. Dalam hal ini terlihat bahwa variabel yang kuat memengaruhi tingkat inflasi adalah adanya demand shock. Dekomposisi varians dari likuiditas menunjukkan pengaruh yang cukup kuat dari demand shock dibandingkan misalnya dengan monetary policy shock, dan nampaknya pengaruh yang paling lemah berasal dari dari shock nilai tukar. Sektor moneter yang direpresentasikan dengan suku bunga sangat dipengaruhi oleh shock GDP riil. Liquidity shock dan inflation shock juga cukup memberikan kontribusi. Dan yang terakhir adalah dari dekomposisi varians exchange rate yang sangat sensitif dari shock inflasi, tetapi tidak sensitif terhadap shock kebijakan moneter.

Sedangkan melalui grafis estimasi impulse response, dapat disimpulkan bahwa pada nilai perubahan suku bunga dan nilai tukar riil rupiah, variabel-variabel endogen keduanya pada jangka panjang akan mendekati konvergensi. Sehingga dapat disimpulkan bahwa apabila terdapat shock yang mengenai variabel suku bunga maupun nilai tukar riil rupiah. Shock tersebut tidak akan bersifat permanen karena, dengan pergerakan variabel menuju konvergensi di periode jangka panjang, menandakan bahwa pengaruh dari shock akan memudar/menurun dengan bertambahnya waktu.

Hal lain yang dapat disimpulkan dari hasil estimasi tersebut adalah variabel-variabel endogenus lebih rentan pada perubahan variabel yang bersumber dari domestik, seperti tingkat likuiditas money demand domestik, dibandingkan variabel yang merupakan efek dari pergerakan atau perputaran kapital secara internasional. Selain itu dapat juga disimpulkan bahwa tingkat atau nilai perubahan suku bunga secara signifikan berhubungan dengan shock yang berhubungan dengan kebijakan moneter. Dengan demikian, variabel nilai perubahan suku bunga dapat digunakan dalam mengurangi potensi risiko yang bersumber dari money demand shock.

Penelitian mengenai pengaruh shock pada kebijakan moneter ini penting mengingat bahwa kestabilitasan makroekonomi didukung oleh kebijakan moneter yang baik. Dengan kestabilan yang tinggi dari variabel-variabel makroekonomi dan sektor perbankan serta meningkatnya sensitivitas dari agen-agen ekonomi terhadap pergerakan suku bunga, maka negara Indonesia diharapkan akan mampu mengimplementasikan strategi kebijakan moneter yang didasarkan pada mekanisme transimisi suku bunga.

\section{DAFTAR PUSTAKA}

Bank Indonesia. (2010). Laporan Kebijakan Moneter 2000-2009. Jakarta: Bank Indonesia. (2010). Laporan Perekonomian Bank Indonesia 2000-2009. Jakarta: Bank Indonesia.

Enders, W. (2010). Applied Econometric Time Series. 3rd Ed. New York: Wiley.

Mirdala, R. (2009). Interest rate transmission mechanism of monetary policy in the selected EMU candidate countries. Munich: MPRA Paper 14072.

Takatoshi, I. and Kiyotaka, S. (2006) Exchange rate changes and inflation in post-crisis Asian economies. NBER Working Paper, 2395.

Taylor, J. B. (1995). The monetary transmission mechanis: An empirical framework. Journal of Economic Perspectives, 9(4), 11-26.

Warjiyo, P. (2004). Mekanisme Transmisi Kebijakan Moneter di Indonesia. Jakarta: PPSK Bank Indonesia. 